\title{
B R I T I S H I N S T I T U T E A T A NKA RA
}

\section{Recent Monographs}

44. At Empires' Edge. Project Paphlagonia: Regional Survey in North-Central Turkey, Roger Matthews and Claudia Glatz (eds). 2009

42. The Black Sea: Past, Present and Future, Gülden Erkut and Stephen Mitchell (eds). 2007

41. Tille Höyük 3.1: The Iron Age. Introduction, Stratification and Architecture, Stuart Blaylock. 2010

40. Çatalhöyük Perspectives: Reports from the 1995-99 Seasons, Ian Hodder (ed.). 2005

39. Changing Materialities at Çatalhöyük: Reports from the 1995-99 Seasons, Ian Hodder (ed.). 2005

38. Inhabiting Çatalhöyük: Reports from the 1995-99 Seasons, Ian Hodder (ed.). 2005

37. Excavating Çatalhöyük: South, North and KOPAL Area Reports from the 1995-99 Seasons, Ian Hodder (ed.). 2006

35. Madra River Delta: Regional Studies on the Aegean Coast of Turkey 1: Environment, Society and Community from Prehistory to the Present, K. Lambrianides and N. Spencer. 2007

34. Greek and Latin Inscriptions in the Burdur Archaeological Museum, G.H.R. Horsley. 2007

32. Canhasan Sites 2. Canhasan I: The Pottery, David French. 2005

31. Anatolian Iron Ages 5, A. Çilingiroğlu and G. Darbyshire (eds). 2005

30. Excavations at Kilise Tepe 1994-98: From Bronze Age to Byzantine in Western Cilicia, Nicholas Postgate and David Thomas (eds). 2007

29. Greek and Latin Inscriptions in the Konya Archaeological Museum, B.H. McLean. 2002

28. Towards Reflexive Method in Archaeology: The Example at Çatalhöyük, Ian Hodder (ed.). 2000

27. Greek, Roman and Byzantine Coins in the Museum at Amasya (Ancient Amaseia), Turkey, S. Ireland. 2000

26. The Ottoman House; Papers of the Amasya Symposium 24-27 September 1996, S. Ireland and W. Bechhoefer (eds). 1998

24. An Epigraphical Survey in the Kibyra-Olbasa Region Conducted by A.S. Hall (Regional Epigraphic Catalogues of Asia Minor III), N.P. Milner. 1998

23. Canhasan Sites 1, Canhasan I: Stratigraphy and Structures, David French. 1998

22. On the Surface: Çatalhöyük 1993-1995, Ian Hodder (ed.). 1997

The publications listed above are available from Oxbow Books

Information about these and other BIAA publications can be found at:

www.oxbowbooks.com 


\section{ANATOLIAN STUDIES \\ Journal of the British Institute at Ankara}

\section{Contents}

A Hittite seal from Kavuşan Höyük. Lorenzo d'Alfonso 1

Hittites and Arzawans: a view from western Anatolia, Naoise Mac Sweeney $\quad 7$

Mycenaean cultural impact on the Çine (Marsyas) plain, southwest Anatolia: the evidence from Çine-Tepecik. Sevinç Günel

How old was the Ankara Silver Bowl when its inscriptions were added?. S.P.B. Durnford

Patterns of Iron Age interaction in central Anatolia: three sites in Yozgat province. Lisa Kealhofer. Peter Grave. Ben Marsh. Sharon Steadman. Ronald L. Gorny and Geoffrey D. Summers

The building complex on the Tepecik acropolis at Patara, Gül Işın

'Pisidian' culture? The Classical-Hellenistic site at Düzen Tepe near Sagalassus (southwest Turkey), H. Vanhaverbeke, M. Waelkens. K. Vyncke, V. De Laet. S. Aydal. B. Mušič. B. De Cupere. J. Poblome. D. Braekmans. P. Degryse. E. Marinova. G. Verstraeten. W. Van Neer. B. Šlapšak. I. Medarič. H.A. Ekinci and M.O. Erbay

A Pannonian auxiliary's epitaph from Roman Gordion. Andrew L. Goldman

A terracotta spacer pin: evidence for a Roman baths at Amorium. Oğuz Koçyiğit

Tools and souvenirs: the shells from Kilise Tepe (1994-1998), Sofie Debruyne 